\title{
Cachimônia: pela alfabetização lenta
}

\section{Resumo}

$\mathrm{Na}$ trajetória histórica da alfabetização, as orientações postas à escrita se deslocaram desde a ideia de que esta seria o 'registro da fala', até a compreensão de que leitura e escrita fluem no complexo esforço intelectual da criança, considerada em sua autoria. $O$ objetivo do estudo que subsidiou este artigo foi investigar escritas infantis a partir do entendimento de que estas escritas seriam a 'representação do pensamento', refutando o determinismo posto pela fala. Como procedimento metodológico, foram coletadas e analisadas escritas infantis, compreendidas enquanto 'mônada' - indissociáveis e plenas de suas próprias histórias. Em sua conclusão, o estudo reivindica uma alfabetização lenta, que acolha as crianças em suas interações, enunciações, discursividades, pensamentos.

Palavras-chave: Alfabetização. Leitura. Escrita.
Mitsi Pinheiro de Lacerda

Universidade Federal Fluminense

- UFF - Rio de Janeiro/Brasil mitsipinheiro@id.uff.br

\section{Para citar este artigo:}

LACERDA, Mitsi Pinheiro de. Cachimônia: pela alfabetização lenta. Revista Linhas. Florianópolis, v. 18, n. 36, p. 347-376, jan./abr. 2017. 


\title{
Cachimônia: think slowly about literacy
}

\begin{abstract}
In the historical trajectory of literacy, orientations about the writing activity have been moved from the idea that it would be the "registration of speech" towards the understanding that reading and writing flow in the complex intellectual effort of the child, considered as an author. The objective of the study that supported this article was to investigate the writings of children, based on the understanding that these writings would be the "representation of thought", therefore refuting determinism presented by speech. The methodological procedure comprises the collection and analysis of such children's writings, understood as "monads" - inseparable from and full of their own stories. In its conclusion, the study claims a slow literacy process, which welcomes children in their interactions, utterances, discourses, and thoughts.
\end{abstract}

Keywords: Literacy. Reading. Writing. 


\section{Introdução}

Fragmento de aula que se perde na lonjura dos tempos, mas que renitentemente, volta. Criticado e banido, ele volta. Classe de alfabetização, aula. Ontem? Hoje? Não sei. Mas abram os cadernos de português, é hora do ditado. A tia vai ditar as palavras e vocês vão escrever nos caderninhos, como já sabem. Caprichem na letra, escutem com atenção. Silêncio. Atenção. Todos prontos? Vamos começar. Senta direito, menino. Vou começar, então. A tia vai falar só uma vez, hein? Vamos lá, ouçam. A primeira palavra é... BA...TA...TA.

Condicionada à acuidade auditiva das crianças e à boa dicção da professora', espantosamente, a escrita tem sido, atualmente, direcionada a ser compreendida enquanto 'registro da fala', e a leitura, a decodificação de caracteres gráficos. Complementar a isso, o aprender implicaria na execução de proposições oferecidas ao aprendiz, e o ensinar se restringiria à elaboração e ordenação de proposições pela professora, acompanhado do exame de sua execução. Esta concepção, que supostamente já teria sido abolida das práticas alfabetizadoras, novamente se materializa em alguns planejamentos escolares, em materiais didáticos, em listas de "habilidades e capacidades" a serem adquiridas, e é possível, também, encontrar seu desenho em cursos de formação destinados a professoras alfabetizadoras.

Amplamente refutada por estudiosos e muitas professoras, a retomada desta formulação no cotidiano escolar implica em práticas pedagógicas alicerçadas no referencial conceitual que se privilegia. Ao tomar a escrita como 'registro da fala', a professora intensifica práticas que conectem o que a criança ouve e diz, àquilo que deve escrever. Daí a fragmentação da palavra, a proliferação de ditados, a repetição de famílias silábicas e o uso exaustivo de palavras canônicas, de forma que a criança busque registrar o que é proveniente da emissão de voz. Nesta prática usual, persiste a crença de que a criança aprende o que lhe é repassado, e de que cabe à professora, uma 'boa emissão oral' que garanta uma 'boa escuta', e seu registro - mesmo que esta ideia já tenha sido refutada há décadas:

\footnotetext{
${ }^{1}$ Considerando a predominância de mulheres atuando nas séries iniciais, optei por utilizar somente o gênero feminino.
} 
Normalmente, pensa-se que para escrever de forma correta é preciso também saber pronunciar de forma correta as palavras. [...] Mas esta premissa baseia-se em duas suposições, ambas falsas: que uma criança de seis anos não sabe distinguir os fonemas do seu idioma, e que a escrita alfabética é uma transcrição fonética do idioma. (FERREIRO; TEBEROSKY, 1984, p. 27)

Concomitante e contrária ao ressurgimento da orientação que a reduz a aspectos fônicos, a alfabetização tem sido investigada, debatida e praticada a partir de outros referenciais. Os esforços de muitos pesquisadores e professores de universidades e escolas, na contemporaneidade, têm resultado no esvaecimento da centralidade metodológica em alfabetização, questionando a primazia do ensino, e transitando através das diferentes lógicas do aprender. Nos últimos trinta anos, no Brasil, desde que os estudos de Emília Ferreiro provocaram mudanças conceituais, percepções críticas têm sido tecidas sobre a professora, a criança, o ambiente alfabetizador, o material didático, a avaliação, os currículos, a leitura e a escrita, o aprender e o ensinar.

Em alfabetização já dispomos, há tempos, de contribuições importantíssimas oferecidas por diferentes autores. Sempre presente, herdamos de Paulo Freire sua luta por uma alfabetização plena e comprometida com a emancipação e a liberdade; uma herança que acolhe a todos (as) e que articula criticamente, em seu interior, toda a problemática política e social. Dentre tantos trabalhos que têm influenciado o que conhecemos sobre o ensino e aprendizagem da leitura e escrita, há importantes contribuições advindas dos estudos sociointeracionistas orientados pelo referencial de Vigotski (2009), dos quais resultou, por exemplo, o entendimento da alfabetização como processo discursivo, desenvolvida em relações de ensino (SMOLKA, 2012). Importantes também são outros trabalhos voltados à alfabetização, ressaltando a grande mudança conceitual (FERREIRO; TEBEROSKY, 1984), assim como os trabalhos que se comprometem com os filhos das classes populares (GARCIA, 1992); os que pensam a alfabetização através de textos (GERALDI, 1984); os que denunciam o reducionismo da avaliação da alfabetização, quando tomada como mensuração (ESTEBAN, 1999). Muito temos aprendido com estudos que registram a trajetória histórica da alfabetização (MORTATTI, 2000); que investigam processos de aquisição da leitura e escrita, se recusando a enquadrá-los em taxonomias (SAMPAIO, 2008); que enfatizam a reflexão 
coletiva e percebem o cotidiano escolar como espaço e tempo de produção de saberes (MORAIS; ARAÚJO, 2007); que legitimam a autoria docente, expressa em narrativas (PRADO;SOLIGO, 2007); que se dedicam a conhecer esta praticante, a professora alfabetizadora (PÉREZ, 2003).

A contribuição destes e também de outros estudos, cujo marco teórico e epistemológico lhes é dialógico, tem investido na ideia de que leitura e escrita são representações em transformação (SMOLKA, 1993, p. 75), universos complexos em que as crianças, envoltas em sua experiência (LARROSA, 2014), atribuem sentidos e trabalham intelectualmente naquilo que leem e escrevem. Ensinar e aprender são vistos em sua indissociabilidade, enquanto diálogo descomprometido com a linearidade e com o suposto estabelecimento de uma temporalidade única. Os estudos destes pesquisadores têm apontado para a imersão na complexidade da alfabetização, para a sua dimensão política e a refutação de práticas desprovidas de sentido.

Quando a alfabetização é compreendida enquanto processo discursivo no qual todos interagem dialogicamente e trabalham em tessituras de sentidos, a prática alfabetizadora se interessa por aquilo que se processa nas relações entre os praticantes e na legitimidade da autoria. Todos são autores e nenhum autor deve ter sua escrita examinada à luz de taxonomias, sobretudo quando se compreende que uma das marcas do trabalho de um autor, é sua originalidade.

Aprendemos com Vigotski (2009, p. 312) que a escrita não repete a história da fala, e que, por isso, a escrita não é o registro da linguagem falada, em signos escritos. Ele ensina que "a escrita é uma função específica de linguagem, que difere da fala" ), afirmando a escrita enquanto linguagem proveniente do pensamento e, portanto, sem qualquer regulação posta pela sonoridade. Para ele, é “o fato de que esta linguagem é apenas pensada e não pronunciada que constitui uma das maiores dificuldades com que se defronta a criança no processo de apreensão da escrita" (VIGOTSKI, 2009, p. 313). Contudo, é comum que cursos de formação continuada orientem a professora a regular as primeiras escritas segundo as emissões da fala, dificultando o exercício autoral. Conforme posto por Vigotski, a escrita é uma linguagem sem interlocutor ou com um interlocutor imaginário; a escola não costuma permitir à criança, a vivência desta situação inusitada, pois insiste na sonorização e 'inventa' uma figura que ‘dita’ as palavras a serem 
escritas: a professora. Na escola, crianças escrevem palavras ditas; pouco tempo Ihes resta para pensarem em suas palavras pensáveis.

A exposição sucinta destas diferentes concepções teve por objetivo registrar a entonação oferecida a este artigo. Enquanto estudiosos e professoras trabalham na direção de uma alfabetização emancipatória, política e tecida a partir dos sentidos postos por quem ensina e aprende, um movimento contrário se agiganta. No interior deste, arquitetos de métodos defendem o ressurgimento da ligação direta entre fala e escrita, e muitas 'entradas' são criadas na escola para possibilitar o acesso desta ideia à professora. Estas 'entradas' ocorrem via cursos de formação continuada, material didático, planejamentos e avaliação externa - e é por meio delas que jorra, sobretudo, a concepção ressuscitada.

No que interessa a este estudo, as orientações postas à escrita se deslocaram desde a ideia de que esta seria o 'registro da fala', até a compreensão de que leitura e escrita são representações que fluem em transformações imersas no complexo esforço intelectual da criança, considerada em sua autoria. Estas formulações apontam para uma prática alfabetizadora interessada nesses fluxos autorais, contrapondo-se às práticas desprovidas de sentido, ao ajustamento da escrita a níveis de conceitualização prescritos e a seu empobrecimento no âmbito de uma dimensão fonética.

Desta forma, é preciso estabelecer que este estudo privilegia a indissociabilidade entre escrita, leitura e linguagem, mas questiona possíveis interpretações que traduzam a escrita como 'registro da fala'. O que questiono, aqui, é um antigo problema que volta, renitente: o reducionismo da escrita à fala. Assim, o objetivo da pesquisa que subsidiou este artigo foi investigar escritas infantis a partir do entendimento de que estas escritas seriam a 'representação do pensamento', refutando o determinismo posto pela fala.

A relevância do estudo residiu na contribuição oferecida aos estudos em alfabetização, ao verificar a apropriação diferenciada de concepções no âmbito das pesquisas e práticas alfabetizadoras. O mecanismo de transposição entre grafemas/fonemas, ainda fortemente presente na literatura e nas concepções/políticas que informam práticas no cotidiano escolar, tem fomentado a ideia que articula a expressão gráfica da escrita, à sonoridade linguística. Com isso, o pensamento - grande 
celeiro responsável pela complexa tarefa de inscrever no mundo a linguagem - é secundarizado, subtraindo-se da relação pedagógica, a investigação sobre os sentidos postos pelo pensar.

Apresento o artigo em cinco breves seções, a saber: primeiramente, faço a exposição sucinta dos caminhos metodológicos que foram traçados através da pesquisa. A seguir, trato da linguística estruturalista enquanto uma das clássicas orientações que, tacitamente, ainda percorrem práticas alfabetizadoras, e sua refutação a partir da teoria da enunciação. A próxima seção é dedicada à negação da soberania da fala, em alfabetização e, posteriormente, trago as escritas de crianças que contribuíram com este estudo. Por fim, em companhia de Michel de Certeau (1994) e Roland Barthes (2006), as considerações finais registram minha modesta contribuição e concordância de que a leitura e a escrita ocorrem processualmente junto à fluidez do pensar, em temporalidades que não são passíveis de uniformidade ou regulação.

\section{Com as mônadas, lições}

O desenvolvimento do estudo que provocou a redação deste artigo, também produziu uma caminhada metodológica. O estudo requeria a coleta de escritas de crianças que ainda não dispõem de proficiência em leitura e escrita, e isso se constituiu em um problema a ser trabalhado. Como e onde coletar estas escritas? Quais seriam os desdobramentos e implicações, caso a opção fosse por coletá-las isoladamente, ou em meio às interações entre várias crianças? Esta questão foi cuidadosamente avaliada, pois é sabido que os procedimentos precisam se ajustar àquilo que se pretende conhecer, e que a coisa a ser conhecida responde ao que lhe é perguntado, utilizando a mesma linguagem presente na indagação (SANTOS, 2002).

Ao tratar da questão do método de investigação, Vigotski (2009) aponta a inexistência de um método que considere o processo de formação de conceitos, e a recorrência metodológica que persegue apenas o produto. Para ele, isso faz com que a palavra seja isolada do material sensorial desde o qual é percebida, e que, "dissociada desse material, transfere todo o processo de definição do conceito para o plano puramente verbal que não é próprio da criança" (VIGOTSKI, 2009, p. 152). A palavra escrita pela criança e analisada em alguns estudos, seria, então, o 'registro da fala' e não 
poderia dizer muito do design que a constitui. É possível notar que, parte das investigações e práticas pedagógicas direcionadas à alfabetização, trabalha com a leitura/escrita de palavras e textos, selecionados e ditos por um adulto alfabetizado. $O$ adulto configura as 'variáveis' que deseja observar (critérios para que o texto seja lido, exigências da criança quanto à variação interna de caracteres, e outros) e direciona a proposição à criança. Quando o adulto alfabetizado opera desta forma, consegue acessar o 'produto' da escrita, e o que consegue observar não é o esforço da criança para oferecer inteligibilidade ao que lhe é proposto. Em muitos casos, até mesmo a 'escrita espontânea' da criança, nasce com a vocação de se adequar a expectativas externas.

Defendendo que o conflito cognitivo se processa em meio a processos sociais e políticos, Smolka (2012) afirma que, em seu estudo, Ferreiro \& Teberosky (1984) observaram a construção da escrita pela criança, individualmente, independente de contextos sociais e relações de ensino. Enquanto estas autoras realizaram seu estudo empírico através da observação das atividades de leitura e escrita oferecidas a crianças em contextos isolados, Smolka trabalhou em classes de alfabetização, junto a professoras e crianças, imersas em situações de ensino e aprendizagem. Os diferentes posicionamentos destas pesquisadoras experientes foram provocativos no delineamento metodológico deste projeto, pois o trabalho empírico teria dimensões epistemológicas diferentes, caso eu optasse por desenvolvê-lo segundo uma, ou outra orientação.

Particularmente, eu preferiria realizar as entrevistas com as crianças individualmente, mesmo que estas entrevistas ocorressem em salas de aula; isto, contudo, implicaria em subtrair as interações e, por conseguinte, faria calar os traços políticos e sociais. A solução para este dilema, a encontrei nos princípios da monadologia de Leibniz (2007), o que passo a explicar a seguir.

Em sua filosofia, Leibniz (2007) discorre sobre as 'mônadas' como sendo substâncias simples, não constituídas de partes, desprovidas de janelas por onde o exterior poderia adentrar e influir em seu interior. Ele aponta sua diferenciação e modificação contínua, com a manutenção de sua singularidade; embora desprovida de 'entradas', uma 'mônada' não dispõe de limites, o que lhe permite ser a expressão de todo o universo. 
Considerando que um conceito não é passível de 'aplicabilidade', busco ajuda na ideia de 'mônada', de forma a provocar o pensamento neste delinear metodológico. Com a 'mônada', me vem a ideia de que os seres vivos, vivenciando a completude de suas singularidades, comportam, em si, algo do que se processa no universo. Vejamos um exemplo para melhor compreensão. Você, leitor (a) deste texto, encontra-se neste momento, obviamente, entregue à leitura deste texto. Embora fisicamente seu corpo esteja voltado a esta atividade, todas as relações (sociais, culturais, religiosas, políticas, laborais e tantas outras) que você vivencia, continuam latentes em você. A sua imersão nesta atividade de leitura não o fragmenta, pelo contrário, aciona continuamente em você, as relações que você privilegia estabelecer entre tudo o que vivencia, tudo o que cria, sente. Para Leibniz, isso seria a percepção, “o estado transitório que envolve e representa uma multiplicidade na unidade, ou na substância simples" (LEIBNIZ, 2007). A 'mônada' não é uma parte, e um ser humano não é uma parte; um ser humano não pode ser dividido em partes.

Temos andado tão preocupados (as) com os procedimentos de nossas pesquisas que, ao discutir o contexto empírico em que elas ocorrem, mantemos a ideia de que, ao distinguir um sujeito de seu grupo social, anulamos o que há de social neste sujeito. Sem desconsiderar a relevância das metodologias participativas e todos os procedimentos metodológicos que prezam pela imersão nas relações humanas, minha opção foi realizar as coletas individualmente, nesta pesquisa. Mesmo considerando a situação ótima que o trabalho de campo em uma sala de aula poderia proporcionar, a especificidade do material coletado, no caso deste estudo, prescindiu da observação das relações entre os praticantes. A opção se justifica por compreender que, no material escrito coletado, estão presentes indícios destas relações, se considerarmos também a escrita enquanto 'mônada' - indissociável e plena de sua própria história.

Para a produção do material necessário ao estudo, foram empregados dois procedimentos distintos: a coleta de escritas de crianças que ainda não são proficientes em leitura/escrita, e a realização de uma enquete mínima com professoras alfabetizadoras. Neste artigo, trago apenas parte das escritas infantis, as quais foram realizadas em espaços educativos formais, não formais e no espaço familiar. Foi aplicado 
um protocolo ${ }^{2}$ único em todas as coletas, o qual indicava a consecução de quatro diferentes tipos de escritas a serem efetuadas pelas crianças. As idades das crianças que contribuíram com este estudo variaram entre quatro e sete anos, sendo que o prérequisito básico era de que esta criança ainda não fosse proficiente em leitura e escrita. $A$ pesquisa ainda se encontra em desenvolvimento e foram entrevistadas, até o momento de produção deste artigo, 25 crianças.

O tratamento oferecido ao material coletado não foi o de submissão a categorias prévias, mas sim, posto como sinalizador dos sentidos a serem descobertos. As escritas das crianças foram tomadas enquanto 'mônadas', plenas de sentido, acompanhadas das marcas de suas trajetórias e de sua experiência (LARROSA, 2014). Ao prescindir do uso de categorias, o tratamento oferecido à coleta de material escrito é isento da obrigatoriedade por se adequar a um reducionismo previamente determinado, e se mostra como enigma a ser trabalhado pela pesquisadora. Cada escrita, uma 'mônada'; cada escrita um universo; cada escrita, uma história atravessada por histórias. A observação de indícios, tais como propõe Ginzburg (1989), foi bastante propícia durante o encontro entre a pesquisadora e o material escrito oferecido pelas crianças. Os indícios sinalizaram 'pontos de bifurcação'3 que direcionaram a interpretação da pesquisadora, favorecendo a inventividade. Penso que a opção pela observação cuidadosa de indícios seria equivalente, talvez, ao procedimento adotado por garimpeiros ${ }^{4}$ artesanais em seu ofício. Caminhando por riachos na busca pelo que lhe interessa - ouro e pedras preciosas - o garimpeiro deixa-se guiar pela ‘faiscação'. Expostos à luz do sol, os minerais faíscam e, faiscando, direcionam o percurso do explorador. Neste sentido, os estudiosos do cotidiano e os garimpeiros empreendem práticas bastante semelhantes, sobretudo se

\footnotetext{
${ }^{2}$ O protocolo constava da solicitação de eince quatro diferentes tipos de escritas: a primeira, escrita a partir da conversa com a entrevistadora sobre os interesses da criança, sem intervenção na grafia; a segunda, cinco palavras canônicas ditadas à criança, segundo o modelo escolar; a terceira, a mostra da figura de uma bola; a quarta, uma frase destacada na conversação com a criança. $\gg \gg$ está faltando o quinto tipo de escrita; aqui só há quatro.

${ }^{3}$ Prigogine \& Stengers (1991), tratando da matéria em situações de não equilíbrio, ressaltam a destruição da homogeneidade e surgimento da "história" - uma vez que, distante do equilíbrio, várias possibilidades se abrem ao sistema. Essas novas possibilidades se configuram a partir daquilo que chamam de "ponto de bifurcação", "ponto crítico a partir do qual um novo estado se torna possível" (p. 122).

${ }^{4}$ Neste texto, refiro-me ao garimpo artesanal de subsistência, fundado em escala individual ou familiar. No garimpo artesanal o controle do trabalho é realizado pelo trabalhador, são empregadas técnicas rústicas tradicionais produzidas a partir da experiência e as relações de trabalho são horizontais e informais.
} 
considerarmos que ambos adentram um campo à busca de preciosidades. Se inicialmente desconhecem onde encontrá-las, durante seu trabalho eles mantêm uma certeza: a de que estas preciosidades existem. Seu caminho não é prescrito, pois que suas trajetórias se delineiam em virtude da sinalização posta pelo faiscar dos achados (LACERDA, 2015, p. 50).

\section{Mustache and beard}

Penso que a prática alfabetizadora ainda tem sido, em grande parte, tomada enquanto problema da linguística estruturalista, ou seja, uma linguística filiada a Saussure. Passados cem anos da publicação atribuída a ele (1916 - 2016), o linguista de bigodes ainda tem influenciado um ensino que se funda na correspondência entre grafemas e fonemas - concepção que se estende até a atualidade. A leitura seria a decodificação das formas gráficas, e a escrita, a codificação da fala. Aqui, o mecanicismo impera absoluto através do delineamento da clássica versão na qual, entre um emissor e um receptor, há uma mensagem que é transmitida linearmente. Nesta ideia gigante e aderente, seu aspecto clean e isento de "ruídos" adentra facilmente as percepções, alimenta as crenças, se materializa em práticas.

Em seu "Curso de Linguística Geral" (que não foi escrito por Saussure, mas compilado a partir de anotações de seus alunos), a língua é tomada enquanto objeto da linguística, e o estruturalismo, o seu método. São amplamente conhecidas as ideias saussureanas: a natureza social da língua e a natureza individual da fala; a rígida oposição/distinção entre língua, linguagem e fala; a função da língua na clarificação do pensamento, que ele define como "massa amorfa"; a imutabilidade do signo e da língua; a composição e recomposição do que se fala e do que se ouve como um processo único; o signo constituído por um mesmo e único significado e significante, utilizado por todos. Para o linguista, o falante compõe o que diz, e o ouvinte usa o mesmo processo para recompor o que ouve. A mensagem é repassada sem perturbações. Alimentado por resquícios de suas ideias, o ensino da leitura e escrita passa a ser reduzido a estudos fonéticos, morfológicos e sintáticos, os quais, embora relevantes na sistematização de conhecimentos linguísticos, não se aplicam ao processo alfabetizador. Exemplo? Basta observar atividades rotineiramente propostas em algumas classes de alfabetização: 
separe as sílabas, dê o coletivo de [...], dê o plural de [...], dê o feminino de [...], circule o adjetivo, pinte a letrinha do seu nome.

Este governo do sistema linguístico foi abalado a partir de Bakhtin (1999) e suas ideias de enunciações que se movem livremente na tessitura de infinitos sentidos. Ele apagou esta 'linha' que supostamente ligaria o que se fala ao que se ouve, inaugurando uma linguagem perturbada com o que há de socioideológico nas vidas das pessoas. Bakhtin deturpou esta linguagem saussuriana limpinha e regulada, iniciando movimentos de busca de sentidos outros, de lógicas outras, de nuances, de tensões, de conflitos. A partir de seu trabalho, aprendemos que os signos não são depositários de significantes, mas da alteridade, e que o que influencia a enunciação são o "ruído" social e a percepção do enunciador, e não a gramática. Depois de Bakhtin, o trono do rei ficou vazio, e pudemos tirar do molho as nossas barbas.

Ao abordar a concepção de linguagem a partir da teoria bakhtiniana, Di Fanti (2003) ressalta a inexistência de uma orientação linear, uma vez que Bakhtin percebe, no discurso, seu movimento dialógico. A autora destaca este movimento do discurso, sinalizando a inexistência de terminalidade - um discurso não tem início, e nem fim. Segundo ela, o discurso em Bakhtin preserva as ressonâncias da linguagem verbal e não verbal, inclusive do que não é dito. O movimento dialógico é carregado de sentidos socioideológicos, de tensões, de história. A dialogia implica em enunciações singulares que não podem ser repetidas, uma vez que o enunciador é outro, a cada momento em que enuncia. A compreensão dos enunciados só é possível no interior das sociedades em que ocorrem, já que estão imersos em teias de complexidades que os afetam recursivamente.

Com Bakhtin, somos todos enunciadores, e a enunciação carrega em si, o que trazemos dos passados e futuros de nossas histórias, fomentando as expectativas em relação ao outro, com indícios furtados na relação. Nas enunciações de todos nós, habita uma tensão permanente entre o quê e com quem falamos, tensionada pelo 'lugar' a partir de onde nos mostramos, para quê nos revelamos, o quanto nos revelamos. A unidade de estudo para Bakhtin é o enunciado que se desenvolve nas tramas da linguagem e é único, acontece uma só vez, repleto dos sentidos de seu devir: o estudo da linguagem deve 
acontecer no interior da linguagem, nos movimentos em que ela se faz, a partir de sujeitos que enunciam seus discursos.

É fabuloso tudo isso, mas, embora as ideias de Bakhtin se aproximem da fluidez da vida, ao inscrever os estudos da linguagem na densidade das relações que se encontram em curso, o idealismo e o positivismo de Saussure ainda persistem nos estudos em ciências humanas e, no interior destas, eu diria também, em alfabetização.

\section{Fala e escrita: distâncias}

Investigando as diferentes formas de pensamento em comunidades de oralidade primária (aquelas em que não há escrita) e em culturas quirográficas (em que há a escrita), Ong (1998) contribuiu para desvelar como as culturas oral e escrita tecem diferentes processos cognitivos. Ele afirma que, nas primeiras, as palavras são sujeitas à sonoridade e a memória é artifício para a aprendizagem, através da repetição oral. É preciso ouvir, repetir o que se ouve, para aprender. O aprender, em comunidades fundadas na oralidade, envolve, basicamente, a percepção auditiva, e o pensamento articula uma oralidade de natureza imediata, voltada à vida cotidiana. Esta conexão única entre a palavra e a sonoridade, afeta os modos de expressão e os processos de raciocínio - estes, mediados por aquilo que se consegue memorizar.

A era da oralidade secundária inscreve a leitura silenciosa, deslocando o foco desde a percepção auditiva, até a percepção visual. Este “deslocamento sensorial”, para Ong, implica em outros usos para a palavra, e para a tessitura do pensamento. Definida por ele como a maior invenção tecnológica, a escrita é inserida artificialmente, e desprovida de uma história natural - o que, paradoxalmente, contribui para a alteração irreversível do discurso e da consciência humana, com a intensificação de seus processos interiores. Através da escrita, a palavra cria autonomia espaçotemporal e isso potencializa as nossas consciências, uma vez que não mais dependemos do meio, do imediato, para compreendê-la. O distanciamento entre autores e escritores no tempo e no espaço, fundado pela escrita, também provoca o refinamento desta, o que redimensiona as atribuições de sentidos. O texto, segundo Ong, é implicado em um paradoxo, pois que, associado à morte e ao distanciamento da vida, é o que permite que esta ressuscite em outros contextos e temporalidades, através da leitura. Embora os primeiros registros 
escritos conhecidos tenham sido produzidos há aproximadamente 6.000 anos, há 100 anos Saussure desconsiderava esta outra natureza da escrita, e a reduzia ao reflexo do discurso oral. Porém, Ong afirma que a escrita não é somente um recurso mnemônico, ou somente uma marca semiótica (um registro realizado por alguém e que dispõe de um sentido), ou somente o registro da enunciação oral; para ele, a escrita "foi e é a mais importante de todas as invenções humanas. Não é um mero apêndice da fala. Em virtude de mover a fala do mundo oral-auricular para um novo mundo sensorial, o da visão, ela transforma tanto a fala quanto o pensamento" (ONG, 1998, p. 100).

Ong apresenta uma pista interessante quando trata da diferença entre a fala e a escrita. Ele explica que o som “existe somente quando está desaparecendo" (ONG, 1998, p. 107) e isso marcaria ainda mais a diferenciação posta, uma vez que a existência de uma palavra escrita se dá quando seu registro é finalizado, e, ainda mais, quando esta palavra escrita se encontra em relação com outras palavras (ou em oposição a elas, como afirma Bakhtin). Entendo isso no sentido de que a fala morre, e a escrita nasce. Embora ambas se atravessem recursivamente, não há qualquer determinação de uma sobre a outra, e o “método" empregado na fala - uma espécie de fade out - seria contrário ao empregado na escrita, o fade in. Como exemplo, vejamos os "ditados" tão usualmente empregados em classes de alfabetização: eles alteram as especificidades da fala e da escrita, pois marcam a fala com uma cadência própria da escrita e reduzem a escrita à codificação da fala.

Ong (1998, p. 104) afirma que o alfabeto só foi inventado uma vez, e Ferreiro \& Teberosky (1984) demonstram que as crianças não empreendem esforços intelectuais para inventarem novas letras. A escrita, em seus primórdios, passou por processos de codificação e, após sua normatização, se fez enquanto linguagem, adentrou o mundo e, desde então, vem alterando a consciência humana (ONG, 1998, p. 93).

Penso que um fonema só interessa a um linguista e a uma professora alfabetizadora que ensina a partir dos sons das letras. Para uma criança que se encontre em processo de aprendizagem da leitura e da escrita, o conhecimento de um fonema é dispensável. A leitura e a escrita podem ser verbalizadas através da fala, mas a fala não as determina, pois, a leitura e a escrita podem acontecer desprovidas de som. Lembro-me de Tobias, que foi meu aluno há vinte anos, quando aprendeu a ler/escrever, e não sabia 
os nomes das letras! Veja o exemplo: ao se deparar com uma placa com os dizeres $<\chi \alpha \delta \varepsilon \rho v o>$ você, leitor, porventura terá necessidade de saber os 'nomes' das letras, de conhecer o 'som' de cada letra ou vai buscar 'pistas' para decifrar o 'sentido' do que está escrito? Você pode compreender o sentido de uma palavra, sem nunca ouvir o som ou conhecer os nomes de suas letras.

Neste artigo, refuto a ideia de que a escrita seria o 'registro da fala' e insisto na proposição de que a escrita seria a 'representação do pensamento'. Esta insistência é acompanhada da sugestão de que a diferenciação posta à escrita, desde o 'registro da fala' até a 'representação do pensamento', implicaria também em diferenciações na prática alfabetizadora, conforme o Quadro 1:

ESCRITA

ENSINO

Registro da fala

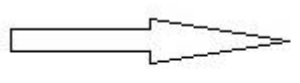

O ensino é mecanicista e fundado no repasse

Representação do pensamento
O ensino é uma prática investigativa

Quadro 1 - Diferenciações na prática alfabetizadora. FONTE: Arquivo Pessoal, 2015.

A conceitualização de escrita que se privilegia, afeta diretamente a prática alfabetizadora. A história da alfabetização registra, por exemplo, que a aderência da conceitualização sobre a escrita, a um suposto aprendiz passivo, desdobrava-se em práticas mecanicistas muito propícias ao adestramento e à violência. Reduzir a escrita ao registro da fala, por sua vez, elimina do exercício escriturístico a miríade de dimensões que o influenciam, reduzindo, também, o ensino a uma questão de repasse. Diferente de tudo isso, o entendimento de que a escrita seria uma representação do pensamento, é 
algo que rompe com quaisquer prescrições postas ao ensino, libertando-o, como nas belas lições freirianas, a revelar-se enquanto prática investigativa.

Segundo Vigotski (2009), o pensamento e a fala não estão diretamente conectados, ou seja, a fala não é representativa de tudo o que se pensa. No fluxo do pensamento são estabelecidas conexões, direcionamentos, velocidades e temporalidades diversas do fluxo verbal e, sendo assim, a fala não registra, oralmente, tudo o que se pensa. No entanto há, em alguns momentos, uma coincidência entre pensamento e linguagem quando, segundo o teórico, é produzido o 'pensamento verbalizado'. Para Vigotski, é possível que o pensamento ocorra sem a simultaneidade da linguagem verbal, assim como é possível que a linguagem verbal ocorra sem a participação do pensamento (ele cita, como exemplo, a emissão verbal de algo que tenha sido memorizado pelo sujeito). Mas vejamos o que interessa neste momento, o conceito de 'pensamento verbal':

\begin{abstract}
Esquematicamente, poderíamos conceber a relação entre pensamento e linguagem como dois círculos que se cruzam, mostrando que em uma parte desse processo os dois fenômenos coincidem, formando o chamado campo do "pensamento verbalizado". Mas este pensamento não esgota todas as formas de pensamento nem de linguagem. Há uma vasta área do pensamento que não mantém relação direta com o pensamento verbal. (VIGOTSKI, 2009, p. 139)
\end{abstract}

Neste 'espaço' de encontro entre pensamento e linguagem, o pensamento verbalizado é produzido quando o que se fala se impregna de sentidos postos pela consciência. No pensamento verbalizado, transposto enquanto 'fala', está contido aquilo que o sujeito privilegia comunicar de seu pensamento, enquanto refuta o que não quer enunciar. Penso que o pensamento verbalizado pode ou não ser registrado sob a forma de escrita, mas esta ocorrência é pouco usual. Não é comum escrevermos o que falamos, a não ser em textos de natureza informativa, prescritiva, mnemônica ou em tarefas escolares. Aprendendo com o conceito de Vigotski, talvez possamos sugerir a existência de uma forma análoga ao 'pensamento verbalizado', o 'pensamento escrito'. Este seria, similarmente àquele, outro 'espaço' de encontro entre o pensamento e a linguagem, implicando no registro gráfico das escolhas conscientes empreendidas entre os infinitos 
dos pensamentos de um autor e os infinitos de possibilidades postas pela linguagem. Vejamos uma possível expressão gráfica para esta ideia:

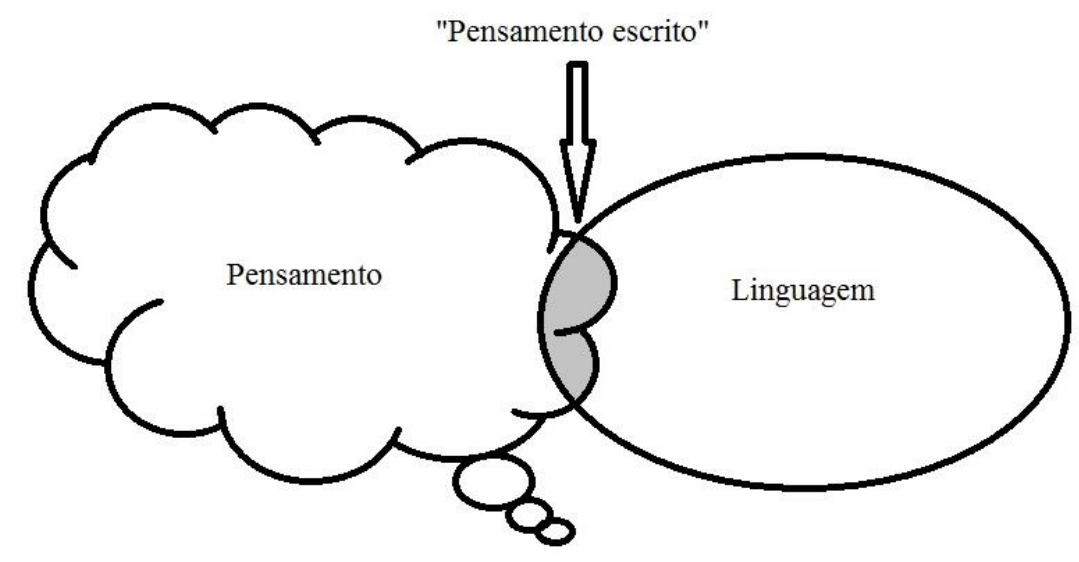

Figura 1 - Expressão gráfica de um suposto 'pensamento escrito', a partir de adaptação de conceito vigotskiano.

FONTE: Arquivo Pessoal, 2015.

O pensamento é um universo em expansão e não poderia jamais ser completamente capturado. Este suposto 'pensamento escrito' seria um campo para onde o autor, mediado pela linguagem e conduzido por um desejo ou uma necessidade, encaminharia o que pudesse capturar da profusão de seu próprio pensar. Diferente do 'pensamento verbal', que imprime velocidade à fala de forma a perseguir o pensamento, o 'pensamento escrito' teria uma natureza nebulosa e lenta, uma vez que sua constituição seria uma complexa trama envolvendo, primordialmente, a linguagem e o pensamento e, secundariamente, o instrumento e a normatização gráfica. Enquanto a fala persegue o pensamento e busca freneticamente comunicá-lo, a escrita requer que o pensamento seja pensado: é uma lapidação. A fala exige instrumentos fisiológicos à sua exteriorização, enquanto a escrita não exterioriza este uso, posto que, na escrita, a fisiologia humana atua nas conexões cerebrais que tecem o pensamento. Escrever seria extrair da nebulosidade de si, uma forma que a representasse; esta forma seria a imagem de um rizoma (GALLO, 2013), um registro gráfico perceptível a seu autor enquanto um, e a seu leitor enquanto outro. A palavra escrita, proveniente do movimento incessante do pensar, provocaria outros pensamentos sem a restrição espaçotemporal. Sua nascente seria o "pensamento escrito", em que esta fabulosa invenção humana ofereceria as 
possibilidades a um registro inerte que, paradoxalmente, desdobra-se infinitamente, enquanto modifica o mundo.

\section{Ah, estas crianças espertas!}

Bastava saber de alguém que fizesse qualquer coisa 'na maior cachimônia", para que eu pousasse meu olhar de admiração sobre esta pessoa. Podia ser um bordado, um cozido, uma carta escrita à mão, a pintura de uma parede - se fosse feito com cachimônia, eu gostava. Com cachimônia era caprichado, era conectado à memória, havia autoria, inteligência e, sobretudo, era uma prática bem pensada. Conheci uma mulher que pintava com cachimônia, detendo-se por dias no artesanato de um 'pano de prato', misturando as tintas e buscando a cor mais bonita do mundo para uma florzinha, para um laço. Conheci um homem que arrumava gavetas; retirava tudo lentamente, limpava, organizava, fazia anotações em uma caderneta e um dia inteirinho se passava. Herdei esta herança que não se compra; que boa sorte eu tive.

O apelo ao excesso, à produção/regulação de desejos e à velocidade vertiginosa através da qual tudo-brota-e-desaparece tem, dentre outros 'assombros' postos pela vida moderna, acelerado nosso ritmo físico e mental na atualidade. Tudo vem, passa e vai, e nós corremos, abrimos os braços, tentamos abarcar o máximo possível, sem sequer observarmos o que buscamos. A vida contemporânea se assemelha ao estouro do balão de guloseimas muito comum em festinhas infantis, quando as crianças se atiram ao chão para garantir o máximo (de qualquer coisa) o mais rapidamente possível (antes dos outros), enquanto os adultos observam a cena, sorrindo. Mas deve haver, dentre estas crianças, uma ou duas que não se atiram ao chão, que não entendem aquilo, que não sorriem ao observar aquilo.

A vida moderna, as políticas educacionais e suas esquizofrênicas listas de 'competências' a serem adquiridas pelas crianças, a temporalidade alfabetizadora regulada por um pacto (sic!), a histórica produção de métodos didáticos, a submissão do ensino e da aprendizagem ao exame, os esforços pela uniformização curricular - tudo isso tensiona o ensino e aprendizagem da leitura e escrita, porque todos têm pressa, para

\footnotetext{
5 Segundo o dicionário "Aulete”, cachimônia significa (1) cabeça; pensamento; inteligência; mente; (2) agudeza de espirito; sagacidade; (3) capacidade de lembrar-se; memória; (4) calma; paciência.
} 
tudo há um prazo, sobre tudo há uma regulação. Programas precisam ser cumpridos, exames precisam ser aplicados, resultados precisam ser tabulados, meninos (as) precisam ser acelerados, professores (as) precisam ser pactuados... e por toda a parte, no chão da escola, vejo apenas desencanto e tristeza, uma tristeza que não me lembro de ter sentido enquanto ensinavaaprendia com os meninos e meninas a boniteza freiriana da palavra, lembranças lindas de práticas alfabetizadoras que ninguém pode explicar, posto que não eram práticas reguladas por agentes externos, mas criadas por mim, meus meninos e meninas, em exercícios de autoria sempre inéditos, inaugurais, nascidos nas delícias dos encontros entre todos (as).

Quando criança, na roça, a época que mais apreciava era a do corte da cana. Todo mundo ia para o canavial, a cana era cortada, transportada no carro-de-boi que cantava sua cantiga lenta, e a cana era levada para a tulha, a palha era derriçada e, no engenho, a cana era moída e o bagaço virava merenda do boi que se fartava também com a capineira, e depois o caldo da cana era posto no tacho de cobre brilhante da vó Olívia que, para meus olhos de criança, era o maior do mundo, e o caldo era bebido, fervido e mexido, e primeiro bebido porque esse caldo nada mais é do que garapa. O pai falava “não fica tão perto do fogo", e depois de um tempo de fervuras vinha a primeira delícia saída do tacho, que era o 'puxa', ponto do caldo antes de ser rapadura, doce derretido, molinho e quente, bom para agarrar no dente e dar dor de barriga, e que mesmo assim a meninada adorava e continuava ali, apreciando a garapa virar melado para ser saboreado com queijo minas verde ou curado, e que quem mexia o tacho suava com o calor da fornalha, se parar embolota e queima, mexia até virar 'puxa', e virar açúcar mascavo, e virar rapadura para adoçar nossas vidas. Ninguém corria, ninguém acelerava: tudo era feito assim mesmo, na maior cachimônia. Rapadura, para mim, nunca foi uma barra de doce, mas uma história de sabores, expectativas, conversas, saberes e muito, muito tempo de trabalho e amorosidade.

Digo tudo isso para pensar a alfabetização, que não há quem negue se tratar de um 'processo', mas que tem sido tomada como um 'produto'. Anteriormente direcionada pelo método, a alfabetização passou a ser também classificada, didatizada, mecanizada; o fabuloso processo alfabetizador que é mediado pelo pensamento da criança, perdeu-se. 
Para ser entendida como um 'processo', é preciso recuperar sua natureza lenta, permitir que seja pensada, reconhecer que nela reside a autoria.

Interessada nesse 'processo', fui ao encontro das crianças e de suas escritas. Minha intenção não foi a de classificar as escritas segundo níveis de conceitualização, mas de buscar pistas que se encontrassem 'entre' dois tipos de escritas: aquelas em que a criança escreveu o que desejava (sem pressa ou regulação), e aquelas em que a criança escreveu palavras que lhe foram ditadas, segundo o modelo escolarizado. Minha intenção foi adentrar este espaço nebuloso 'entre’ as escritas.

A observação das escritas sugeriu uma primeira trilha investigativa, quando percebi distinções nas escritas de uma mesma criança: havia uma escrita convencional e não convencional, ao mesmo tempo. Em meio à conversa, quando foi solicitado às crianças que ajudassem no trabalho, escrevendo o que gostassem, as crianças escreveram algo tecido em seus pensamentos, e então, os registros não se enquadraram na norma convencional e não se comprometeram com o modelo alfabético. Logo a seguir, quando escreveram as palavras 'canônicas' ditadas pelas entrevistadoras', as crianças reproduziram escritas escolarizadas, registrando as palavras no formato alfabético, resultando em escritas convencionais. Neste momento, elas espelhavam a lógica escolar e comunicavam uma escrita ajustada a esta norma. Na escrita de Gabi (Fig. 2), percebemos isso. Enquanto conversava e pensava no que Ihe interessava, Gabi contou que gostava muito de praia, pensou, demorou... e então escreveu: CA NA CA. A seguir, foi solicitado a ela que escrevesse a palavra 'pato', e, rapidamente, ela registrou: PTOA.

\footnotetext{
${ }^{6}$ Participaram desta etapa da pesquisa as bolsistas de iniciação científica CNPq/UFF Laysla Lobo e Lafânia Mendes, e as colaboradoras, estudantes do curso de Pedagogia/UFF, Thuany Rezende, Angelina Ferreira e Quésia Pereira.
} 


\section{CANA CA}

\section{PToA}

Figura 2 - Escrita de Gabi, 6 anos.

FONTE: Arquivo Pessoal, 2015.

Ao escrever CA NA CA, é possível que Gabi não tenha se dedicado a atender expectativas alheias. Ela participou da conversa, pensou, escreveu e se mostrou em sua autoria. A seguir, veio o PATO. Ah, o pato... o pato, o sapo, o gato e todas estas palavras canônicas formadas por consoante e vogal, palavras da escola, palavras que provavelmente diziam à Gabi: 'aqui você não pode pensar, é preciso acertar'. Ela quase acertou: lembrou-se das letras que lhe foram ensinadas, mas esqueceu-se da 'ordem' em que deveria dispô-las, porque aqui, o que ela registrava, era o que ela recuperava da lição escolar, as letras 'certas' em uma ordem 'correta'. A escritora Gabi, menina que gostava de CA NA CA, desapareceu, momentaneamente. Será que a menina pode escrever sobre a CA NA CA na escola? Será que a escola está contente ao verificar que a menina sabe escrever PATO?

Com Priscila aconteceu algo tão comum nas escolas: Priscila copiou da colega. Priscila chegou, sentou perto da amiga que estava terminando sua escrita, e, desde aí, não perdeu seus movimentos de vista. A colega escrevia, Priscila copiava. Priscila, em pouco tempo de escola, já aprendeu que na escola há o 'certo' e o 'errado', e que ela precisa 'acertar'. Para acertar, precisa aprender a perversa lição de que sua própria escrita é ruim, e que para ocultar isso, ela copia da amiga, essa amiga que acerta sempre, essa amiga que ganha o sorriso da professora. Priscila, então, copiou as palavras canônicas que foram ditadas: MALA, PÁ, PATO, ABACAXI, SAPO, LATA. Mas a amiga acabou 
depressa a tarefa, foi embora e Priscila ficou sozinha; faltava a ela ainda escrever uma palavra ditada, 'jabuticaba', e então ela grafou assim: ABU GAEMA (Fig. 3).

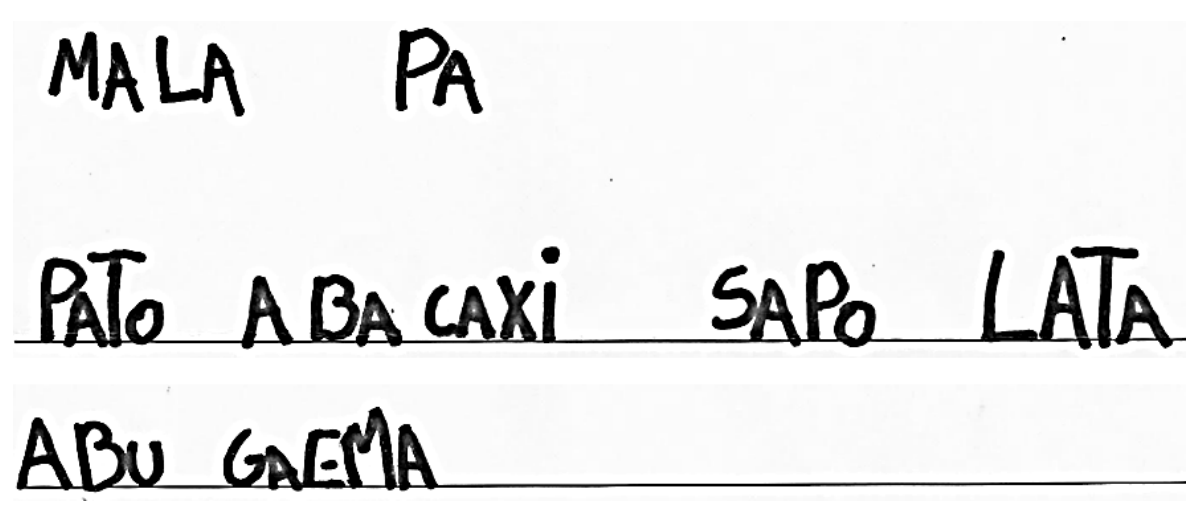

Figura 3 - Escrita de Priscila, 6 anos.

FONTE: Arquivo Pessoal, 2015.

A mesma criança, durante a mesma atividade, grafa palavras de formas tão diferenciadas. Seria muita ingenuidade pensar que Priscila não percebe isso, porque já vimos que Priscila é esperta. Ela já entendeu a lógica escolar, apesar de não ter se submetido ao mecanicismo que regula a formação de famílias silábicas ou à 'consciência fonética'. Se com Vigotski aprendemos que as crianças aprendem umas com as outras em interação, e que a 'cola' é uma possibilidade para que isso ocorra, penso que a cola, aqui, ocorreu a partir de outra função: colar para acertar, e não colar para ajudar a pensar.

A escrita de Luiza, apesar de graficamente ser parecida com a de Priscila, não foi copiada. Luiza participou da conversa inicial, concordou em colaborar com o estudo, pensou, demorou... disse que gostava de assistir TV e que gostava de brigadeiro, que tudo isso era uma delícia. Então ela pensou, demorou... e registrou não o que conversou, mas o que considerou mais adequado escrever. Nesta primeira escrita (que para preservar o anonimato não é mostrada aqui), na qual supostamente ela escreveria 'televisão' e 'brigadeiro', Luiza escreveu o nome da escola e o nome de sua professora, conforme o cabeçalho que é colocado no quadro de giz, diariamente. Luiza também é esperta, e deve ter pensado: 'Ah, eis aí outra professora, não posso errar'. A seguir, grafou rapidamente as palavras canônicas que lhe foram ditadas (pá, pato, abacaxi, sapo, lata, mala), tudo muito certinho. Concluída esta escrita, travamos uma conversa e então 
eu Ihe contei que tenho um pé de jabuticaba no quintal de casa, e que as jabuticabas já estavam maduras, e que o morcego as saboreava antes de mim, que coisa, não é mesmo? Ela, então, disse que gostava de jabuticaba também, que engolia com caroço e tudo, e concordou em escrever: A JABUTICABA JÁ ESTÁ MADURA. Nesta escrita, Luiza não se deixou conduzir por aquilo que lhe fora ensinado, e nem ajustou sua escrita a possíveis expectativas que eu teria, pois que grafou a frase (AGBUCAAOBAGALITADA) conforme pode ser lido na parte inferior da Figura 4:

\section{PA}

\section{PATO ABACAXI SAPO LATAMALA}

\section{AGBUCA AOBAGALITBOA}

Figura 4 - Escrita de Luiza, 6 anos. FONTE: Arquivo Pessoal, 2015.

A mesma criança, a mesma entrevistadora, a mesma conversa e a mesma folha de papel. Nas escritas, Luiza mostra que aquilo que a escola considera que ela sabe, na verdade, é o que ela memorizou; porém, penso que o que ela sabe, ainda se encontra em processo, o qual ela oculta, camufla. Sociedade e escola sorriem ao verificarem que a criança sabe escrever PATO. É comum ouvirmos "minha filha já sabe escrever várias palavras!”, como se esta 'competência' tivesse algum valor cognitivo para a criança. Não, minha senhora, sua filha não sabe escrever ainda... ela apenas aprendeu uma lição de escola, aprendeu a memorizar para repetir e cumprir a tarefa que lhe foi atribuída. Esta 'lição de escola', talvez ela nem tenha aprendido a partir desta escola atual; poderíamos dizer que se trata de uma 'herança', algo que se transmite tacitamente apesar de muitas práticas pedagógicas sinalizarem sua refutação. Uma criança ingressa na escola e já sabe que vai sentar-se sozinha na carteira, que terá um caderno para cada disciplina, que para fazer xixi terá que pedir, que será submetida a avaliações. Ela sabe que precisará 
aprender a ler e a escrever e também sabe que há uma forma 'correta' de se fazer isso. Mesmo que sua professora trabalhe em outra direção, esta é a herança com a qual a criança adentra a escola.

Mas as crianças são espertas. Elas aprendem em um piscar de olhos que a letra ' $A$ ' é a letra do 'avião' e que é preciso falar várias vezes ' $A$ ', ' $A$ ', ' $A$ ' até convencer a tia de que já sabe isso. Em pouquíssimo tempo entendem o mecanismo que agrega uma consoante a uma vogal, assim como percebem quais destes mecanismos são socialmente aceitos. Em estágio mais avançado, já sabem que no 'passe para o plural' basta acrescentar um 'S', e que no 'separe as sílabas' basta colocar duas letras, um tracinho, duas. Disso resultam palavras canônicas corretas, estrelinhas douradas (sim, elas ainda existem), todo mundo contente. Já a outra escrita, aquela não convencional, aquela que perturba quando percebida, é entregue à classificação demarcada pelos níveis de conceitualização, e pouco se desconfia de que ali reside um esforço intelectual de outra natureza. Alfabeticamente incorreta, esta outra escrita é levada pelo pensamento e não se enquadra nas lições escolares aprendidas. Tão logo é percebida, é capturada e direcionada, e o mistério da menina que escreve de forma convencional e não convencional simultaneamente, permanece mudo em uma folha de caderno que, certamente, tem uma orelha na banda onde ela esfrega o cotovelo.

\section{Pensamento e escrita: aproximações}

Diferentes orientações sobre a natureza da leitura e da escrita resultaram em distinções na prática alfabetizadora, ora afirmando práticas convencionais, ora questionando o ensino-repasse e a aprendizagem-reprodução, ora empreendendo bricolagens entre tudo isso. Se em algum momento o ensinar da professora e o aprender da criança foram dicotomizados e formatados linear e verticalmente, atualmente é sabido que entre o ensinar e o aprender residem processos de negociação, refutação, invenção e, muito especialmente, recursividade. O olhar curioso para este espaçotempo complexo tem provocado deslocamentos no pensamento de quem se dedica à alfabetização, dando a conhecer, continuamente, que alfabetização é uma questão de autoria. Contrário a isso, permanece viva, ainda, a crença de que a linguagem escrita é o registro da fala e, com isso, alguns olhares continuam a regular os movimentos produzidos pelas crianças neste 
suposto trabalho de 'transposição' da fala para a escritura. A escrita, contudo, não dispõe de qualquer compromisso com esta transposição, e nem expressa, em si, a totalidade do que poderia ser. Vejamos um pouco mais sobre isso.

Discorrendo sobre práticas que resguardam os vivos, da experiência em curso naquele que morre, Certeau aponta o momento em que o desejo de dizer, do moribundo, é silenciado, "censurado, privado de linguagem, envolto numa mortalha de silêncio: inominável” (CERTEAU , 1994, p. 294). Pede-se ao quase morto que descanse, que não diga nada. Para Certeau, o tratamento dispensado pelos vivos, àquele que morre, o desloca para um lugar onde os viventes não estão, um lugar que não lhes pertence, pois a morte seria o “índice de toda alteridade" (CERTEAU, 1994, p. 297). O isolamento é imposto ao moribundo; não lhe é possível a linguagem enquanto se aproxima da morte, um outro lugar. À escrita, Certeau constata a mesma perda posta ao moribundo, uma vez que escrita e morte ocorrem na perda. Escrever seria perder o que se produz, enquanto se ganha uma expectativa, já que "a experiência escriturística se desdobra segundo o modo da relação entre o ato de avançar e o solo mortífero onde se traça a sua itinerância" (CERTEAU, 1994, p. 302). A escrita se constitui como registros parciais de algo mais amplo do que ela poderia ser, pois muito do que se cria e do que se pensa, perde-se em meio ao ato de escrever, enquanto se grafa. Metaforicamente, penso que a escrita seria aquilo que resta em nossas mãos após tentarmos conter, em seu interior, as nuvens que criamos em pensamento. A escrita é sempre menos do que poderia ser, e Certeau ressalta a impossibilidade da representação de todo o processo que a envolve. A escrita inscreve seu próprio sacrifício. Seu acontecer implica também na produção de seu apagamento, pois "soletra uma ausência que é o seu preâmbulo e seu destino final” (CERTEAU, 1994, p. 299).

Durante a escrita, estamos 'fora' das convenções da escrita, estamos no lugar da elocução e não nos lugares de onde advém o sistema de escrita, uma vez que "o lugar de onde se fala é exterior ao empreendimento escriturístico. A elocução sobrevém fora dos lugares onde se fabricam os sistemas de enunciados" (CERTEAU, 1994, p. 252). Quando a criança escreve o que pensa, ela 'erra' porque foge do encarceramento das normas e se entrega aos próprios sentidos que cria. Já quando a criança escreve as palavras canônicas, observa, sobretudo, a correção das junções entre vogais e consoantes, 
registrando o texto 'correto' a partir da lógica escolar. É a este trabalho, isento de esforço intelectual, que a sociedade atribui legitimidade. A primeira escrita, autoral, seria tão somente o passaporte para o fracasso.

Quanto à leitura, ainda é possível encontrar em algumas classes de alfabetização o projeto de decodificação de um 'código', fazendo coincidir esse ‘código' com a emissão de voz do leitor. Este projeto se contrapõe, na escola, a belíssimas iniciativas nas quais a polissemia da leitura delineia múltiplos sentidos para os leitores. A leitura, em Certeau, é uma prática cotidiana cujo 'produto' não é capitalizado por não ser circunscrito no tempo - ela “introduz portanto uma 'arte' que não é passividade” (CERTEAU, 1994, p. 50). A leitura não resulta em um produto imediato ao seu acontecer; ela hiberna e se desdobra infinita e incontrolavelmente - daí a impossibilidade de sua capitalização. A leitura não se restringe ao material de leitura e nem ao espaçotempo onde ocorre, mas estabelece conexões entre tudo isso e a experiência do leitor. Não se lê tão somente o que está escrito; o que é lido resulta, sobretudo, do consumo do texto, quando o mundo do leitor “se introduz no lugar do autor" (p. 49). A leitura, como prática, não é passiva, e seu acontecer não se dirige a quaisquer regulações universais. Diferente disso, em grande parte, até que obtenha proficiência em leitura, o 'aprendiz' é conduzido institucionalmente por trilhas canônicas, enquanto astuciosamente opera táticas anônimas de apropriação. O 'aprendiz' nem sempre é percebido como 'praticante', como usuário da língua, como caminhante que percorre, observa e modifica o mundo. Ao ingressar na classe de alfabetização, a leitura da criança costuma ser gradualmente orientada, e sua escrita observada a partir de taxonomias, fruto do texto teórico. Mas, onde está você, menino? O que olha? Como vê o que olha? O que pensa sobre o que vê? O que escreve sobre o que pensa? O que lê através do seu pensar?

Ao ler e escrever, o sujeito se põe a pensar. Pensa seu pensamento, instância da liberdade. Ler e escrever são indissociáveis do pensar: "Leio e me ponho a pensar... Minha leitura seria então a minha impertinente ausência. Seria a leitura um exercício de ubiquidade?" (ROSOLATO, apud CERTEAU, 1994, p. 269). Penso que sim, a leitura seria a possibilidade de transitar, livre e simultaneamente, por diferentes espaços e tempos. Contudo, leitura e escrita permanecem, em grande parte, historicamente dicotomizadas e aprisionadas: ainda persiste o direcionamento a uma lógica hegemônica que, se na Idade 
Média teve sua interpretação regulada pela igreja (MANGUEL, 1997; GINZBURG, 1987), hoje é reduzida aos interesses do capital. Na trajetória histórica da alfabetização, o ensino da leitura e da escrita percorreram caminhos prescritos, nos quais o pensar não poderia se mostrar. Foram postos à leitura e à escrita artifícios de mecanização, obstáculos criados ao pensamento. Há séculos, o mecanicismo opera no sentido de ignorar o que de mais fabuloso atravessa e complexifica a história da leitura e da escrita: a tessitura do pensamento, este fluído incontrolável que inscreve sentidos de liberdade por onde passa.

Para Barthes (2006, p. 22), a escrita “está sempre enraizada num além da linguagem, desenvolve-se como um germe e não como uma linha”. Quando há rupturas em quaisquer esferas que impliquem em acontecimentos históricos, revoluções científicas ou transformações sociais, as mentalidades e consciências também se modificam, afetando todo o tecido social em espacialidades e temporalidades diversas. Esta mudança de consciência afeta rapidamente a escrita e a linguagem, mas não interfere nos aspectos fônicos da fala. Alteramos o que dizemos e escrevemos continuamente no perturbador fluxo social, utilizando os mesmos fonemas que nossos antepassados. Apenas isso seria suficiente para sugerirmos que a escrita não representa a fala (cujos aspectos fônicos sofrem pouquíssimas mudanças no decorrer dos tempos), mas que representa o pensamento tecido pela História.

A ocorrência de práticas alfabetizadoras desprovidas de sentido alimenta a forma, “mecanismo parasitário da função intelectual” (BARTHES, 2006, p. 75). Este mecanismo pode ser encontrado nas fragmentações postas ao texto, nas proposições didáticas voltadas ao domínio do código e em outras engenhosidades que persistem em classes de alfabetização. Com isso, a escrita por vezes é conduzida desde sua expressão gráfica, esquecendo-se que esta expressão gráfica deveria ser tão somente o registro final de um denso trabalho intelectual. Fazendo-me valer da "metáfora da viagem" tão cara ao pensamento cartesiano, é como se esta viagem ignorasse seu devir e tivesse início na aquisição do souvenir, já que "à situação do pensamento se mistura um destino suplementar, muitas vezes divergente, sempre incómodo, da forma" ( BARTHES, 2006, p. 75).

Se a leitura e a escrita se processam através da fluidez do pensar, então não é possível submetê-las a quaisquer esquemas que as prescrevam ou a parâmetros que as 
examinem. Elas não são passíveis de serem submetidas à mensuração parcelar de 'habilidades, capacidades e competências' determinadas externamente. O pensamento que alimenta a leitura e a escrita não se constitui como um corpo sólido passível de ser entregue a uma evolução linear e à manipulação externa. Ele é, sobretudo, difuso, browniano $^{7}$. O registro do pensamento é algo que comumente deixa esvair fluxos que o constituem, ao mesmo tempo em que incorpora outros fluxos nascentes. A leitura e a escrita ocorrem em meio a algo que nasce e desaparece permanentemente, o pensamento. De sua marcação gráfica inicial, a leitura e escrita tornam-se outras ao acontecer, pois que o pensamento pulula inquieto. A escrita marca sobre um portador de textos o que o autor consegue capturar do movimento vertiginoso do seu pensar, e a leitura reescreve vertiginosamente aquilo que, aparentemente, já se encontrava findo.

Leitura e escrita são bricolagens, e bricolagens operam sobre aquilo que foi desprovido de sua função inicial. O que orienta a leitura e a escrita de um sujeito alfabetizado é seu pensamento, sobrepondo-se a normas canônicas aplicadas às letras. Já o ensino destinado às crianças costuma investir no contrário, uma vez que elas não são provocadas a se orientarem primordialmente pelos infinitos de seus pensamentos, mas sujeitadas a limitar suas trajetórias, segundo uma referência terminal. Toda a normatização posta a este modelo de alfabetização é acompanhada da regulação temporal e adequação cronológica do aprender.

Se a escrita de um sujeito proficiente refuta a reflexão sobre aspectos técnicos para perseguir os sentidos que tece, a escrita de um sujeito em processo de conhecer costuma ser regulada segundo uma lógica que não distorce ou posterga, mas que nega a sua reflexão. É um aprisionamento no interior de um processo que sequer dispõe de limites ou leis; a escrita, aprisionada na normatividade canônica, dificilmente poderá ser a expressão do pensamento.

É preciso que não se tome a audição e a visão como preceptores para a leitura e a escrita, mas que se entenda que um ser humano é completamente atravessado por ramificações de sentidos que o conectam ao mundo, e que estes rizomas também são tecidos pelo ver e pelo ouvir, mas que como bons rizomas, não distinguem estas funções

\footnotetext{
7 Nos estudos em física, "movimentos brownianos" são movimentos aleatórios empreendidos através da colisão de partículas, promovendo organizações caóticas e não lineares.
} 
em hierarquias. Por isso reivindico uma alfabetização lenta, que acolha as crianças em suas interações, enunciações, discursividades, pensamentos. Uma alfabetização isenta de temporalidades demarcadas, de conteúdos especificados, de destino certo. Queria apenas uma alfabetização lenta, pensada. Que coisa fascinante seria encontrar uma criança assim, escrevendo, lendo, na maior cachimônia do mundo.

\section{Referências}

BAKHTIN, Mikhail (Volochinov). Marxismo e filosofia da linguagem. São Paulo: Hucitec, 1999.

BARTHES, Roland. 0 grau zero da escrita. Lisboa: Edições 70, 2006.

CERTEAU, Michel de. A invenção do cotidiano. Artes de fazer. Petrópolis: Vozes, 1994.

DI FANTI, Maria da Glória. A linguagem em Bakhtin: pontos e pespontos. Veredas, Juiz de Fora, v. 7, n. 1, p. 95-111, jan./dez. 2003.

ESTEBAN, Maria Teresa (Org). Avaliação: uma prática em busca de novos sentidos. Rio de Janeiro: DP\&A, 1999.

FERREIRO, Emília; TEBEROSKY, Ana. Psicogênese da língua escrita. Porto Alegre: Artes Médicas, 1984.

GALLO, Sílvio. Deslocamento 3. Rizoma e Educação. In: . Deleuze \& a Educação. Belo Horizonte: Autêntica, 2013.

GARCIA, Regina Leite (Org.). Alfabetização dos alunos das classes populares. São Paulo: Cortez, 1992.

GERALDI, João Wanderley. 0 texto na sala de aula: leitura \& produção. Cascavel: Assoeste, 1984.

GINZBURG, Carlo. O queijo e os vermes: o cotidiano e as ideias de um moleiro perseguido pela Inquisição. São Paulo: Companhia das Letras, 1987.

GINZBURG, Carlo. Mitos, emblemas, sinais: morfologia e história. São Paulo: Companhia das Letras, 1989.

LACERDA, Mitsi Pinheiro de. A alfabetização e o alfabetizar. Imagens da educação, Maringá, v. 5, n. 1, p. 46-56, jan./abr. 2015.

LARROSA, Jorge. Tremores: escritos sobre experiência. Belo Horizonte: Autêntica, 2014. 
LEIBNIZ, Gottfried Wilhelm Von. Princípios de filosofia ou monadologia. 2007. Disponível em: <http://www.leibnizbrasil.pro.br/leibniz-pdf/monadologia.pdf >. Acesso em $12 / 09 / 2014$.

MANGUEL, Alberto. Uma história da leitura. São Paulo: Companhia das Letras, 1997.

MORAIS, Jacqueline de Fátima dos Santos; ARAÚJO, Mairce da Silva. Alfabetização: desafios da prática alfabetizadora. Revista Acolhendo a Alfabetização nos Países de Língua Portuguesa. Disponível em: <http://www.mocambras.org>. Acesso em: 10/08/2013.

MORTATTI, Maria do Rosário Longo. Os sentidos da alfabetização (São Paulo 1876/1994). São Paulo: Ed. UNESP, 2000.

ONG, Walter. Oralidade e cultura escrita. Campinas: Papirus, 1998.

PÉREZ, Carmen Lúcia Vidal. Professoras alfabetizadoras: histórias plurais, práticas singulares. Rio de Janeiro: DP\&A, 2003.

PRADO, Guilherme do Val Toledo; SOLIGO, Rosaura (Orgs). Porque escrever é fazer história. Campinas: Alínea, 2007.

PRIGOGINE, Ilya; STENGERS, Isabelle. A nova aliança: metamorfose da ciência. Brasília: Editora UnB, 1991.

SAMPAIO, Carmen Sanches. Alfabetização e formação de professores. Rio de Janeiro: Wak Editora, 2008.

SANTOS, Boaventura de Sousa. Um discurso sobre as ciências. Porto: Edições Afrontamento, 2002.

SMOLKA, Ana Lúcia Bustamante. A criança na fase inicial da escrita. A alfabetização como processo discursivo. São Paulo: Cortez, 2012.

VIGOTSKI, Lev Semenovich. A construção do pensamento e da linguagem. São Paulo: Martins Fontes, 2009. 